\title{
Pengaruh Profitabilitas, Leverage, Ukuran Perusahaan Terhadap Nilai Perusahaan Dengan CSR Sebagai Moderating Variable Pada Perusahaan Manufaktur di BEI
}

\author{
Mipo \\ Universitas IBBI \\ mipo.ibbi@gmail.com
}

\begin{abstract}
Diajukan
: 24 Desember 2021

Disetujui

: 11 Januari 2022

Dipublikasi

: 11 Januari 2022
\end{abstract}

\begin{abstract}
This study aims to analyze factors that influence company value and then to test the influence of corporate social responsibility on company value. The variables examined in this study are independent variable consisted of profitability, leverage, and company size. The dependent variables that used are company value and corporate social responsibility as a moderating variable.The population that used in this research is the manufacturing industries listed in 20162020 consisted of 143 companies. This study has 23 companies as sample that chosen based on the purposive sampling method. Data analysis technique used is multiple linear regression analysis using SPSS $v 25$ application.The results of this study indicate that partially profitability had a significant positive effect on company value. Meanwhile, leverage and company size had no effect on company value. On the other side partially corporate social responsibility had a significant positive effect on company value. As moderating variable corporate social responsibility could moderate correlation of leverage with company value. While the correlation of variables profitability and company size could not.The conclusion of this researh is partially profitability and corporate social responsibility had significant positive effect on company value. While the variables of leverage and company size did not. And then corporate social responsibility could moderate correlation of leverage with company value. While the correlation of variables profitability and company size could not.
\end{abstract}

Keywords: Corporate Social Responsibility; Company Value; Company Size; Leverage; Profitability

\section{PENDAHULUAN}

Tujuan pendirian perusahaan jangka panjang adalah mengoptimalkan nilai perusahaan karena ketika nilai perusahaan tinggi maka akan disertai oleh tingginya kesejahteraan pemegang saham. Semakin tinggi tingkat harga saham, maka akan semakin tinggi pula nilai perusahaan yang menunjukkan prospek perusahaan ke depannya, serta mencerminkan total aset yang dimiliki perusahaan. Nilai perusahaan dalam dunia usaha mengalami persaingan yang semakin pesat sehingga membuat setiap perusahaan berusaha meningkatkan kinerjanya serta menerapkan strategi-strategi yang tepat agar tujuannya dapat tercapai. Salah satu cara untuk memaksimalkan nilai perusahaan adalah melalui profitabilitas. Profitabilitas mencerminkan keuntungan dari investasi keuangan, semakin baik pertumbuhan profitabilitas perusahaan berarti prospek perusahaan di masa depan dinilai semakin baik, artinya nilai perusahaan juga akan dinilai semakin baik di mata investor (Bidhari dkk, 2013). Ketika perusahaan dapat meningkatkan kemampuannya untuk menghasilkan laba maka harga saham perusahaan tersebut akan meningkat. Dengan demikian analisis profitabilitas ini memiliki pengaruh yang sangat besar bagi para investor dan karena alasan inilah maka perusahaan berupaya keras dalam memaksimalkan sumber daya yang ada untuk mencapai profit yang ditargetkan oleh perusahaan guna memaksimalkan 
kemakmuran pemegang saham.

Berikut adalah data perkembangan nilai kapitalisasi pasar pada perusahaan manufaktur yang terdaftar di Bursa Efek Indonesia periode tahun 2016 sampai tahun 2020.

Tabel 1. Perkembangan Nilai Kapitalisasi

\begin{tabular}{|c|l|l|}
\hline No & Tahun & Nilai Kapitalisasi Pasar \\
\hline 1 & 2016 & Rp 69.584.880.012.500 \\
\hline 2 & 2017 & Rp. 66.950.752.062.500 \\
\hline 3 & 2018 & Rp. 65.414.177.425.000 \\
\hline 4 & 2019 & Rp. 69.365.369.350.000 \\
\hline 5 & 2020 & Rp. 60.145.921.525.000 \\
\hline
\end{tabular}

Sumber : (www.idx.co.id) 2021

Berdasarkan Tabel 1. di atas dapat dilihat bahwa nilai kapitalisasi pasar pada perusahaan manufaktur pada tahun 2016-2017 mengalami penaikan nilai kapitalisasi pasar, sedangkan pada tahun 2017-2018 nilai kapitalisasi pasar pada perusahaan manufaktur mengalami penurunan, sedangkan 2018-2019 nilai kapitalisasi pasar mengalami penaikan dan 2019-2020 nilai kapitalisasi mengalami penurunan. Maka dapat disimpulkan bahwa nilai kapitalisasi pasar periode 2016-2020 berflukutuasi. Selain memiliki peranan penting dalam pembangunan, terlebih lagi dalam menghadapi era persaingan bebas, perusahaan manufaktur dituntut semakin efektif dalam mempublikasikan laporan keuangannya, dimana sektor manufaktur dianggap sektor yang dapat menilai secara keseluruhan perusahaan di Indonesia, karena terdiri dari banyak jenis industri..

Yang dapat menggambarkan besar kecilnya suatu perusahaan yang dinyatakan dengan total aset adalah ukuran perusahaan (Dewi dkk, 2013). Ketika perusahaan memiliki total aset yang semakin besar maka akan semakin besar pula ukuran perusahan tersebut dan semakin besar pula modal yang akan di tanam. Ketika perusahaan memiliki kinerja keuangan yang baik pihak investor akan semakin yakin maka akan semakin besar pula ukuran perusahaan tersebut, Ukuran perusahaan merupakan faktor yang menentukan dalam nilai perusahaan. Ukuran perusahaan diukur menggunakan Logartima Natural dari total aset. Ukuran perusahaan mencakup besar kecilnya perusahaan dilihat dari total aset..

Faktor lain yang dapat mempengaruhi nilai perusahaan adalah leverage. Rasio leverage merupakan rasio yang menggambarkan tentang kemampuan perusahaan untuk memenuhi kewajibannya baik dalam jangka pendek maupun jangka panajang. Menurut Dewi dkk (2013) Leverage menunjukkan kemampuan dari suatu perusahaan untuk memenuhi segala kewajiban finansial dari perusahaan tersebut seandainya perusahaan tersebut dilikuidasi. Penggunaan hutang yang terlalu banyak tidak baik karena dikhawatirkan bahwa akan terjadi penurunan laba yang diperoleh perusahaan. Artinya, ketika nilai leverage yang semakin tinggi maka akan dapat menimbulkan investasi yang dilakukan beresiko besar, sedangkan nilai leverage yang kecil akan menunjukkan investasi yang dilakukan beresiko kecil. Leverage dapat diukur menggunakan Debt to Equity Ratio (DER).

Corporate Social Responsibility (CSR) dapat didefinisikan sebagai komitmen bisnis untuk memberikan kontribusi bagi pembangunan ekonomi yang berkelanjutan, melalui kerja sama dengan para pemangku kepentingan perusahaan untuk meningkatkan kualitas kehidupan dengan cara yang bermanfaat baik bagi bisnis sendiri maupun untuk pembangunan (Hardian dan Asyik, 2016). Ketika perusahaan memiliki keuntungan yang semakin besar, semakin besar kemampuan perusahaan dalam melaksanakan CSR yang berpengaruh terhadap kepercayaan stakeholder yang nantinya tentu dapat meningkatkan nilai perusahaan tersebut, begitu pula sebaliknya.

Oleh karena itu hubungan CSR dalam melakukan moderasi terhadap profitabilitas, leverage, ukuran perusahaan dan nilai perusahaan terdapat hubungan yang signifikan dan mempengaruhi dalam hubungan langsung antara variabel independen dan variabel dependen. 


\section{STUDI LITERATUR}

Cara perusahaan untuk mengoptimalkan tujuan jangka panjang perusahaan adalah dengan cara memperhatikan atau meningkatkan profitabilitas, leverage, ukuran perusahaan dan nilai perusahaan serta adanya corporate social responsibility (CSR) yang dapat memaksimalkan kegiatan perusahaan terhadap seluruh pihak pemangku kepentingan baik itu dalam ekonomi, sosial maupun lingkungan.

\section{Profitabilitas}

Rasio profitabilitas yaitu rasio yang digunakan untuk menilai kemampuan perusahaan dalam mencari keuntungan (Kasmir (2014), sedangkan menurut Kamil dan Herusetya (2012), berpendapat bahwa tingkat profitabilitas yang semakin besar menunjukkan perusahaan mampu mendapatkan laba yang semakin besar, sehingga perusahaan mampu untuk meningkatkan aktivitas tanggung jawab sosial, serta mengungkapkan tanggung jawab sosialnya dalam laporan tahunan dengan lebih luas.

Return on Asset (ROA) merupakan salah satu rasio profitabilitas yang menunjukkan kemampuan perusahaan dalam menghasilkan laba. Semakin besar rasio ini maka profitabilitas perusahaan akan semakin baik. ROA merupakan rasio yang menunjukkan hasil (return) atas jumlah aset yang digunakan dalam perusahaan. Rasio ini menunjukkan berapa besar laba bersih yang diperoleh perusahaan diukur dari nilai asetnya. Analisis ROA atau sering dalam bahasa Indonesia sebagai rentabilitas ekonomi, mengukur perkembangan perusahaan menghasilkan laba. Hipotesis menunjukan bahwa profitalitas mempengaruhi variabel pengungkapan nilai perusahaan

\section{Leverage}

Penggunaan sumber-sumber pembiayaan perusahaan, baik yang merupakan sumber pembiayaan jangka pendek maupun jangka panjang akan menimbulkan suatu efek yang biasa disebut dengan leverage. Menurut Rodoni dan Ali (2014: 123), leverage mencerminkan kemampuan perusahaan dalam memenuhi seluruh kewajibannya yang ditunjukkan oleh beberapa bagian modal sendiri yang digunakan untuk membayar hutang. Sehingga dapat disimpulkan bahwa yang dimaksud dengan leverage adalah suatu tingkat kemampuan perusahaan dalam menggunakan aktiva dan atau dana yang mempunyai beban tetap (hutang dan atau saham istimewa) dalam rangka mewujudkan tujuan perusahaan untuk memaksimisasi kekayaan pemilik perusahaan.

Permasalahan leverage akan selalu dihadapi oleh perusahaan, bila perusahaan tersebut menanggung sejumlah beban atau biaya, baik biaya tetap operasi maupun biaya finansial. Biaya tetap operasi merupakan beban atau biaya tetap yang harus diperhitungkan sebagai akibat dari fungsi pelaksanaan investasi, sedangkan biaya finansial merupakan beban atau biaya yang harus diperhitungkan sebagai akibat dari pelaksanaan fungsi pendanaan. Jadi, beban atau biaya tetap sebenarnya merupakan risiko yang harus ditanggung perusahaan dalam pelaksanaan keputusankeputusan keuangan. Hipotesis menunjukan bahwa leverage mempengaruhi variabel pengungkapan nilai perusahaan

\section{Ukuran Perusahaan}

Dalam skala usaha terdapat berbagai ukuran perusahaan yang berbeda, dari perusahaan kecil sampai dengan perusahaan besar perbedaan tersebut tergantung pada investasi yang ditanamkan. Apapun ukuran perusahaannya tujuan yang ingin dicapai tetap sama yaitu suatu perusahaan didirikan adalah untuk menghasilkan laba bagi pemiliknya. Ukuran perusahaan adalah besar kecilnya perusahaan dilihat dari besarnya nilai equity.

Dalam pengukuran ukuran perusahaan dapat ditentukan dengan berbagai nilai seperti total aset, penjualan, modal, laba dan yang lainnya, nilai tersebut dapat menentukan besar kecilnya perusahaan. Berkembangnya suatu perusahaan dari perusahaan kecil hingga menjadi besar tidak lepas dari peran manajer perusahaan dalam mengelola sumber daya pemilik perusahaan (Hariyani, dkk 2011). Menurut Taliyang, dkk (2011) ukuran perusahaan diukur dengan menggunakan logaritma natural total aset. Skala pengukurannya adalah skala rasio. Semakin besar aset biasanya ukuran perusahaan tersebut semakin besar. Hipotesis menunjukan bahwa ukuran perusahaan mempengaruhi variabel pengungkapan nilai perusahaan 


\section{Nilai Perusahaan}

Nilai perusahaan dalam penelitian ini didefinisikan sebagai nilai pasar, karena nilai perusahaan dapat memberikan kemakmuran pemegang saham secara maksimum apabila harga saham perusahaan meningkat. Menurut Birgham dan Daves (2010:211) semakin tinggi harga saham, maka makin tinggi kemakmuran pemegang saham. Suatu perusahaan dikatakan mempunyai nilai yang baik jika kinerja perusahaan juga baik. Nilai perusahaan dapat tercermin dari harga sahamnya. Jika nilai sahamnya tinggi bisa dikatakan nilai perusahaannya juga baik. Nilai perusahaan dalam penelitian diukur menggunakan Price Book Value (PBV). Perusahaan yang memiliki PBV dengan nilai yang semakin tinggi menunjukkan bahwa prospek pertumbuhan perusahaan semakin baik, karena investor akan mengeluarkan pengorbanan yang lebih untuk perusahaan yang memiliki nilai pasar aset yang lebih besar daripada nilai bukunya. Hipotesis menunjukan bahwa nilai perusahaan mempengaruhi variabel pengungkapan nilai perusahaan

\section{Corporate Social Responsibility}

Corporate Social Responsibility atau CSR merupakan suatu bentuk kesungguhan perusahan dalam memisahkan sebagian dari kekayaan perusahaan untuk meminimalisir dampak negatif yang mungkin saja bisa terjadi akibat dari kegiatan perusahaan, dengan berusaha memaksimalkan dampak positif dari kegiatan perusahaan terhadap seluruh pihak pemangku kepentingan baik itu dalam ekonomi, sosial maupun lingkungan. Karagiorgos (2010 : 85) menyatakan bahwa corporate social responsibility (CSR) merupakan komitmen berkelanjutan yang dilakukan dalam dunia usaha untuk berperilaku etis dan berkontribusi terhadap pembangunan ekonomi sekaligus meningkatkan kualitas hidup tenaga kerja dan keluarganya serta komunitas lokal dan masyarakat luas.

\section{METODE}

Metode penelitian adalah suatu kegiatan yang menggunakan metode sistematis untuk memperoleh data yang meliputi pengumpulan data, pengelolaan data dan analisis data. Menurut Sugiyono (2017), yang dimaksud dengan metode penelitian adalah sebagai berikut metode penelitian pada dasarnya merupakan cara ilmiah untuk mendapatkan data dengan tujuan dan kegunaan tertentu.

Jenis penelitian yang digunakan dalam penelitian ini adalah penelitian kuantitatif dengan pendekatan kausalitas (sebab-akibat). Menurut Chandrarin (2017 : 135), jenis penelitian ini merupakan jenis penelitian yang digunakan untuk menguji pengaruh, hubungan atau dampak variabel independen terhadap variabel dependen.

Dalam operasional penelitian ini terdiri dari 3 variabel yaitu dependen, independen dan moderasi.

\section{Variabel Dependen}

Nilai perusahaan merupakan persepsi investor terhadap perusahaan, yang sering dikaitkan dengan harga saham. Nilai perusahaan dapat diukur menggunakan PBV. Price to Book Value (PBV) menggambarkan seberapa besar pasar menghargai nilai buku saham suatu perusahaan

$$
P B V=\frac{\text { Harga pasar per lembar saham }}{\text { Laba per lembar saham }}
$$

\section{Variabel Independen}

Variabel independen sering disebut sebagai variabel stimulus, predictor, antecedent. Menurut Sugiyono (2017) :"Variabel bebas merupakan variabel yang mempengaruhi atau yang menjadi sebab perubahan atau timbulnya variabel dependen (terikat)." Maka dalam penelitian ini variabel independen yang diteliti adalah Profitabilitas $\left(X_{1}\right)$, Leverage $\left(X_{2}\right)$, dan Ukuran Perusahaan $\left(X_{3}\right)$.

Profitabilitas merupakan rasio untuk menilai kemampuan perusahaan dalam mencari keuntungan atau laba dalam suatu periode tertentu (Kasmir, 2014). Pada penelitian ini profitabilitas diproksi dengan menggunakan Return on Asset. Return on Asset (ROA) merupakan rasio yang menunjukkan hasil (return) atas jumlah aktiva yang digunakan dalam perusahaan (Kasmir, 2014). Pada penelitian ini profitabilitas diproksi dengan menggunakan Return on Asset. 
Owner: Riset \& Jurnal Akuntansi

e-ISSN : 2548-9224 | p-ISSN : 2548-7507

Volume 6 Nomor 1, Januari 2022

DOI : https://doi.org/10.33395/owner.v6i1.614

Return on Asset (ROA) merupakan rasio yang menunjukkan hasil (return) atas jumlah aktiva yang digunakan dalam perusahaan. Return On Asset (ROA) dapat dihitung dengan beberapa rumus sebagai berikut:

$$
\text { Return On Assets }=\frac{\text { Laba bersih setelah pajak }}{\text { Total assset }}
$$

Leverage adalah penggunaan aset dan sumber dana perusahaan yang memiliki biaya tetap dengan maksud agar meningkatkan keuntungan potensial pemegang saham. (Kasmir, 2014).

$$
\text { Debts total asset ratio }=\frac{\text { Total utang }}{\text { Total assset }}
$$

Ukuran perusahaan adalah besar kecilnya perusahaan dilihat dari besarnya nilai equity, nilai penjualan atau nilai aktiva.

$$
\text { Ukuran perusahaan }=\operatorname{Ln}(\text { asset })
$$

\section{Variabel Moderasi}

Variabel Moderator adalah variabel yang mempengaruhi baik itu memperkuat atau memperlemah hubungan antara variabel bebas dan terikat. Maka dalam penelitian ini variabel moderator yang diteliti adalah adalah Corporate Social Responsibility (Z).

CSR (Corporate Sosial Responsibility) secara harifiah adalah respon sosial atau tanggung jawab sosial terhadap lingkungan sekitar yang dilakukan oleh sebuah perusahaan dalam bentuk berbagai kegiatan (Mardikanto, 2014). Pengungkapan diukur dengan menggunakan rumus penghitungan Corporate Social Responsibility Disclosure Index berdasarkan GRI (Global Reporting Initiative):

$$
\operatorname{CSR}_{i}=\frac{\sum X_{i j}}{N_{j}}
$$

\section{Uji Statistik Deskriptif}

Data dalam penelitian ini dianalisis dengan statistik deskriptif. Statistik deskriptif digunakan untuk mengetahui tingkat profitabilitas, leverage, ukuran perusahaan, nilai perusahaan dan corporate social responsibility pada perusahaan manufaktur yang terdaftar di BEI. Pengukuran yang digunakan dalam penelitian ini adalah nilai minimum, nilai maximum, mean, dan standar deviasi (Gozali, 2016).

\section{Uji Asumsi Klasik}

Pengujian asumsi klasik ini bertujuan untuk mengetahui dan menguji kelayakan atas model regresi yang digunakan dalam penelitian ini. Pengujian ini juga dimaksudkan untuk memastikan bahwa didalam model regresi yang digunakan tidak terdapat multikolonieritas, heteroskedastisitas dan autokolerasi serta untuk memastikan bahwa data yang dihasilkan berdistribusi normal.

\section{Analisis Regresi Linear Berganda}

Analisis regresi yang digunakan dalam pengolahan data pada penelitian ini adalah analisis regresi linier berganda (multiple linear regression), karena dalam penelitian ini melibatkan beberapa variabel bebas (Independen) dan satu variabel terikat (Dependen).

Model pengujiam dalam penelitian ini dapat dirumuskan dalam persamaan sebagai berikut:

$$
Y=a+b_{1} X_{1}+b_{2} X_{2}+b_{3} X_{3}+e
$$


Owner: Riset \& Jurnal Akuntansi

e-ISSN : 2548-9224 |p-ISSN : 2548-7507

Volume 6 Nomor 1, Januari 2022

DOI : https://doi.org/10.33395/owner.v6i1.614

Keterangan :

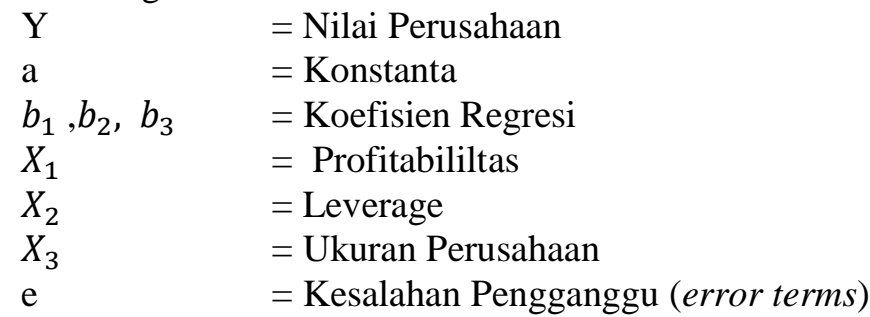

Analisis Deskriptif

HASIL

Tabel 2. Analisis Deskriptif Setelah di Outlier

Descriptive Statistics

\begin{tabular}{|l|c|c|c|c|c|}
\hline & $\mathbf{N}$ & Minimum & Maximum & Mean & Std. Deviation \\
\hline Profitabillitas & 94 &, 0003 &, 2500 &, 069278 &, 0546010 \\
Leverage & 94 &, 0190 &, 7800 &, 444670 &, 1805871 \\
U.Perusahaan & 94 & 12,4755 & 18,9101 & 15,385496 & 1,7331898 \\
N.Perusahaan & 94 &, 0816 & 8,0774 & 2,000635 & 1,7287054 \\
CSR & 94 &, 1519 &, 3924 &, 302173 &, 0641503 \\
Valid N (listwise) & 94 & & & & \\
\hline
\end{tabular}

Uji Asumsi Klasik

Dalam uji asumsi klasik ini terdiri beberapa uji seperti yang terlihat dibawah ini:

\section{Uji Normalitas}

Tabel 3. Uji Normalitas

One-Sample Kolmogorov-Smirnov Test

\begin{tabular}{|ll|c|}
\hline & & Unstandardized Residual \\
\hline $\mathrm{N}$ & & 94 \\
Normal Parameters & Mean &, 0000000 \\
& Std. Deviation & 1,19947703 \\
Most Extreme Differences & Absolute &, 089 \\
& Positive &, 089 \\
& Negative &,- 055 \\
Test Statistic &, 089 \\
Asymp. Sig. (2-tailed) &, $064^{\mathrm{c}}$ \\
\hline \multicolumn{2}{|c|}{ Sumber : Hasil data olahan SPSS 25 ,2021 } \\
\hline
\end{tabular}

\section{Multikolienaritas}

Tabel 4. Multikolinearitas

\begin{tabular}{|c|c|c|}
\hline \multirow[b]{2}{*}{ Model } & \multicolumn{2}{|c|}{ Collinearity Statistics } \\
\hline & Tolerance & VIF \\
\hline (Constant) & & \\
\hline Profitabilitas & 675 & 1,482 \\
\hline Leverage & 683 & 1,463 \\
\hline U.Perusahaan & ,960 & 1,042 \\
\hline CSR & ,954 & 1,049 \\
\hline
\end{tabular}

Sumber : Hasil data olahan SPSS 25,2021 


\section{Heteroskedastisitas}

Tabel 5. Uji Heteroskedasitas

\begin{tabular}{|cc|c|}
\hline & & \\
& Model & Sig. \\
\hline 1 & (Constant) &, 350 \\
& I_X1 &, 748 \\
& I_X2 &, 515 \\
& I_X3 &, 605 \\
& I_Z &, 210 \\
\hline
\end{tabular}

Sumber : Hasil data olahan SPSS 25,2021

\section{Uji Autokorelasi}

Tabel 6. Uji Autokerelasi

Model Summary ${ }^{b}$

\begin{tabular}{|l|l|l|l|l|l|}
\hline & & & & & \\
Model & $\mathbf{R}$ & R Square & Adjusted R Square & Std. Error of the Estimate & Durbin-Watson \\
\hline 1 &, $635^{\mathrm{a}}$ &, 403 &, 377 & 8,64967 & 1,612 \\
\hline
\end{tabular}

a. Predictors: (Constant), Za, X2a, X3a, X1a

b. Dependent Variable: Ya

\section{Uji Regresi Linear Berganda}

Tabel 7. Koefisien Regresi Linear Berganda

\section{Uji Hipotesis}

\begin{tabular}{|c|c|c|c|}
\hline \multirow{2}{*}{\multicolumn{2}{|c|}{ Model }} & \multicolumn{2}{|c|}{ Unstandardized Coefficients } \\
\hline & & B & Std. Error \\
\hline \multirow[t]{4}{*}{1} & (Constant) & 2,330 & 1,346 \\
\hline & Profitabillitas & 19,354 & 2,885 \\
\hline & Leverage & $-1,245$ & ,870 \\
\hline & U.Perusahan &,- 073 & ,076 \\
\hline
\end{tabular}

Sumber : Hasil data olahan SPSS 25,2021

Pengujian hipotesis terdiri dari beberapa pengujian seperti yang terlihat dibawah ini:

Uji Signifikan Parsial ( Uji Satistik t )

Tabel 8. Uji Signifikan Parsial ( Uji t )
\begin{tabular}{|c|c|c|c|}
\hline \multicolumn{1}{|c|}{ Model } & T & Sig. \\
\hline \multirow{2}{*}{1} & (Constant) &, 368 &, 714 \\
& Profitabilitas & 6,616 &, 000 \\
& Leverage & $-1,354$ &, 179 \\
& U.Perusahaan &,- 638 &, 525 \\
& CSR & 2,257 &, 026 \\
\hline
\end{tabular}

Sumber : Hasil data olahan SPSS 25,2021 
Owner: Riset \& Jurnal Akuntansi

e-ISSN : 2548-9224 |p-ISSN : 2548-7507

Volume 6 Nomor 1, Januari 2022

DOI : https://doi.org/10.33395/owner.v6i1.614

\section{Uji Signifikan Simultan ( Uji Statistik F)}

Tabel 9. Uji Signifikan Simultan ( Uji F )

\begin{tabular}{|c|c|c|c|}
\hline \multicolumn{2}{|c|}{ Model } & F & Sig. \\
\hline 1 & Regression & 28,941 &, $000^{\mathrm{b}}$ \\
& Residual & & \\
& Total & & \\
\hline
\end{tabular}

Sumber : Hasil data olahan SPSS 25,2021

\section{Uji Koefisien Determinasi}

Model Summary ${ }^{\mathrm{b}}$

Tabel 10. Uji Koefisien Determinasi

\begin{tabular}{|c|c|c|c|c|}
\hline Model & R & R Square & Adjusted R Square & Std. Error of the Estimate \\
\hline 1 &, $720^{\mathrm{a}}$ &, 519 &, 497 & 1,226135 \\
\hline
\end{tabular}

a. Predictors: (Constant), CSR, Leverage, U.Perusahaan, Profitabilitas

b. Dependent Variable: N.Perusahaan

Sumber : Hasil data olahan SPSS 25,2021

\section{Moderated Regresion Analysis}

Tabel 11. Uji Signifikansi CSR dalam Memoderasi Pengaruh Profitabilitas Terhadap Nilai

Perusahaan

\begin{tabular}{|c|c|c|c|c|}
\hline \multirow{2}{*}{ Model } & \multicolumn{2}{|c|}{ Unstandardized Coefficients } & \multirow{2}{*}{ Sig. } \\
\cline { 3 - 4 } & B & Std. Error &, 170 \\
& (Constant) & $-1,629$ & 1,179 &, 035 \\
& Profitabillitas & 31,105 & 14,544 &, 062 \\
& CSR & 7,101 & 3,755 &, 481 \\
\hline
\end{tabular}

Sumber : Hasil data olahan SPSS 25,2021

$$
Y=-1,629+31,105 X 1+7,101 Z-31,249 X I Z
$$

Tabel 12. Uji Signifikasi CSR dalam Memoderasi Pengaruh Leverage terhadap Nilai Perusahaan

\begin{tabular}{|c|c|c|c|c|}
\hline \multicolumn{2}{|c|}{ Model } & \multicolumn{2}{c|}{ Unstandardized Coefficients } & \multirow{2}{*}{ Sig. } \\
\cline { 3 - 4 } 1 & (Constant) & $-4,533$ & Std. Error &, 150 \\
& Leverage & 9,842 & 3,122 &, 136 \\
& CSR & 26,692 & 6,544 &, 007 \\
& X2Z & $-44,401$ & 9,711 &, 033 \\
\hline
\end{tabular}

Sumber : Hasil data olahan SPSS 25,2021

$$
Y=-4,533+9,842 X 2+26,692 Z-44,401 X 2 Z
$$


Tabel 13. Uji Signifikasi CSR dalam Memoderasi Pengaruh Ukuran Perusahaan terhadap Nilai Perusahaan

\begin{tabular}{|c|c|c|c|c|}
\hline \multirow{2}{*}{ Model } & \multicolumn{2}{|c|}{ Unstandardized Coefficients } & \multirow{2}{*}{ Sig. } \\
\cline { 3 - 4 } \multicolumn{2}{c|}{1} & B & Std. Error &, 939 \\
& (Constant) &,- 545 & 7,115 &, 957 \\
& U.Perusahan &, 026 &, 474 &, 588 \\
& CSR & 12,417 & 22,828 &, 822 \\
\hline
\end{tabular}

Sumber : Hasil data olahan SPSS 25,2021

$$
Y=-, 545+0,026 X 3+12,417 Z-0,346 X 3 Z
$$

\section{PEMBAHASAN}

Berdasarkan Tabel 2 hasil analisis deskriptif setelah di outlier, menunjukan bahwa data yang di analils sebanyak 94 data observasi yang diproleh dari laporan tahunan 23 perusahaan manufaktur yang terdaftar di BEI selama jangka waktu 5 tahun dari 2016-2020 penjelasannya terhadap variabel-variabel penelitian yang di gunakan sebagai berikut :

Profitabilitas; Variabel $X_{1}$ Profitabiltas yang diukur dengan rasio Return on Asset dengan berjumlah sebanyak 94 observasi $(\mathrm{N})$ menunjukan bahwa nilai minuman 0,0003 sedangkan nilai maksimal 0,2500 dengan nilai rata-rata (mean) 0,69278 dan standar deviasi sebesar 0,1813046 artinya selama periode penelitian, ukuran penyebaran dari variabel pengungkapan nilai perusahaan adalah sebesar 0,1813046 dari 94 observasi.

Leverage; Variabel $X_{2}$ Leverage yang diukur dengan rasio Debt to Total Asset Ratio dengan berjumlah sebanyak 94 sobservasi $(\mathrm{N})$ menunjukan bahwa nilai minuman 0,0190 sedangakan nilai maksimal 0,7800 dengan nilai rata-rata (mean) sebesar 0,444670 dan standar deviasi sebesar 0,1813046 artinya selama periode penelitian, ukuran penyebaran dari variabel pengungkapan nilai perusahaan adalah sebesar 0,444670 dari 94 observasi.

Ukuran Perusahaan; Variabel $X_{3}$ Ukuran Perusahaan yang diukur dengan Ln (Asset) dengan berjumlah sebanyak 94 sobservasi $(\mathrm{N})$ menunjukan bahwa nilai minuman 12,4755 sedangakan nilai maksimal 18,9101 dengan nilai rata-rata (mean) 15,385496 dan standar deviasi sebesar 1,7331898 artinya selama periode penelitian, ukuran penyebaran dari variabel pengungkapan nilai perusahaan adalah sebesar 1,7331898 dari 94 observasi.

Nilai Perusahaan; Variabel Y Nilai Perusahaan yang diukur dengan Price to Book Value (PBV) dengan berjumlah sebanyak 94 sobservasi $(\mathrm{N})$ menunjukan bahwa nilai minuman 0,0816 sedangakan nilai maksimal 8,0774 dengan nilai rata-rata (mean) 2,000635 dan standar deviasi sebesar 1,7287054 artinya selama periode penelitian, ukuran penyebaran dari variabel pengungkapan nilai perusahaan adalah sebesar 1,7287054 dari 94 observasi.

Corporate Sosial Responsibility (CSR); Variabel Z Corporate Sosial Responsibility (CSR) yang diukur dengan dengan Corporate Social Responsibility Disclosure Index berdasarkan GRI (Global Reporting Initiative) berjumlah sebanyak 94 sobservasi $(\mathrm{N})$ menunjukan bahwa nilai minuman 0,1519 sedangakan nilai maksimal 0,3924 dengan nilai rata-rata (mean) 0,302173 dan standar deviasi sebesar 0,0641503 artinya selama periode penelitian, ukuran penyebaran dari variabel pengungkapan nilai perusahaan adalah sebesar 0,0641503 dari 94 observasi.

Pada Tabel 3 diatas didapatkan hasil One Sample Kolmogorov-Smirnov, yang mana nilai signifikansi untuk keseluruhan variabel $>0,05$ yaitu sebesar 0,064. Yang artinya, data dalam penelitian ini berdistribusi normal.

Pada Tabel 4 diatas, maka dapat disimpulkan bahwa :

a. Pada variabel Profitabilitas, terlihat bahwa nilai tolerance $>0,10$ yaitu sebesar 0,675 dan nilai VIF < 10 yaitu sebesar 1,482. maka dapat disimpulkan bahwa tidak ada multikolinearitas.

b. Pada variabel Leverage, terlihat bahwa nilai tolerance $>0,10$ yaitu sebesar 0,683 dan nilai VIF $<10$ yaitu sebesar 1,463. Maka dapat disimpulkan bahwa tidak ada multikolinearitas.

c. Pada variabel Ukuran Perusahaan, terlihat bahwa nilai tolerance $>0,10$ yaitu sebesar 0,960 dan nilai VIF < 10 yaitu sebesar 1,042. Maka dapat disimpulkan bahwa tidak ada multikolinearitas. 
d. Pada variabel CSR, terlihat bahwa nilai tolerance $>0,10$ yaitu sebesar 0,954 dan nilai VIF $<10$ yaitu sebesar 1,049. Maka dapat disimpulkan bahwa tidak ada multikolinearitas. Berdasarkan hal diatas, didapatkan semua variabel diatas tidak ada yang mengalami multikolinearitas. karena masing-masing variabel diatas memiliki nilai tolerance besar dari 0,10 dan nilai VIF kecil dari 10.

Berdasarkan hasil uji Glejser pada Tabel 5 di atas, dapat dilihat bahwa nilai signifikan dari Profitabilitas sebesar 0,748, leveragesebesar 0,515, dan Ukuran Perusahaan sebesar 0,605, dan Corporate Sosial Responsibility sebesar 0,210 lebih besar dari 0,05 maka dapat disimpulkan hasil pengujian ini menunjukkan bahwa tidak terjadi gejala heteroskedastisitas pada penelitian ini. Pada Tabel 6 nilai Durbin Watson sebesar sebesar 1,612. Dalam penelitian ini jumlah sampel sebanyak 94 dan jumlah variabel bebas 4 , sehingga diperoleh nilai dU sebesar 1,7538 dan nilai dL sebesar 1,5768. Nilai 4 - du sebesar 1,7776 maka dU < DW < 4 - dU $(1,5542<1,612<2,2224)$. Sehingga dapat disimpulkan bahwa hasil penelitian ini tidak terjadi masalah autokorelasi dan dapat dilanjutkan ke penelitian selanjutnya.

Pada Tabel 7 di atas maka persamaan linear berganda dalam penelitian ini adalah:

$\mathrm{Y}=2,330+19,354 \mathrm{X} 1-1,245 \mathrm{X} 2-0,073 \mathrm{X} 3$, dan hal ini telah membuktikan bahwasannya penelitian ini dapat berjalan dengan konsisten yang dijabarkan dari nilai matematis yang terdapat pada persamaan linear berganda dalam penelitian ini.

Pada Tabel 8 diatas, maka dapat dilihat bahwa:

1. Profitabillitas secara parsial berpengaruh signifikan terhadap Nilai Perusahaan. Hal ini ditunjukkan dengan nilai signifikansinya $<0,05$ yaitu sebesar 0,000 dengan nilai t hitung $>$ dari t tabel yaitu $6,616>1,986$.

2. Leverage secara parsial tidak berpengaruh signifikan terhadap Nilai Perusahaan. Hal ini ditunjukkan dengan nilai signifikansinya > 0,05 yaitu sebesar 0,179 dengan nilai t hitung < dari t tabel yaitu $-1,354<1,986$.

3. Ukuran Perusahaan secara parsial tidak berpengaruh signifikan terhadap Nilai Perusahaan. Hal ini ditunjukkan dengan nilai signifikansinya $>0,05$ yaitu sebesar 0,525 dengan nilai t hitung < dari t tabel yaitu $-0,638<1,986$.

4. Corporate Sosial Responsibility secara parsial berpengaruh signifikan terhadap Nilai

Perusahaan. Hal ini ditunjukkan dengan nilai signifikansinya $<0,05$ yaitu sebesar 0,026 dengan nilai t hitung > dari t tabel yaitu 2,257>1,986.

Pada Tabel 9 Diketahui nilai f hitung 28,941 dan nilai signifikansi 0,000. Nilai signifikansi lebih kecil 0,05 dan nilai $f$ hitung 28,941 > f tabel 2,706. Hal ini menunjukan bahwa variabel independen berpengaruh secara simultan terhadap variabel dependen. Berdasarkan ini dapat disimpulkan bahwa profitabilitas, leverage, ukuran perusahaan secara simultan berpengaruh terhadap nilai perusahaan.

Pada Tabel 10 Nilai Adjusted R Square sebesar 0,497 mengindikasikan bahwa 0,497 variasi variabel pengungkapan Nilai Perusahaan yang mampu dijelaskan oleh variabel Profitabilitas, Leverage, Ukuran Perusahaan, dan Corporate Sosial Responsibility (CSR) sedangkan sisanya 0,503 dijelaskan oleh variabel lain. Nilai R 0,720 menunjukkan bahwa koefisien korelasi atau keeratan hubungan antara Profitabilitas, Leverage,Ukuran Perusahaan, dan Corporate Sosial Responsibility (CSR) dengan pengungkapan Nilai Perusahaan memiliki posisi yang 0,720.

Pada Tabel 11 diperoleh persamaan moderasi sebagai berikut:

Diketahui untuk nilai sig untuk baris X1Z adalah 0,481 >0,05, maka dapat disimpulkan corporate sosial responsibility tidak signifikan dalam memoderasi pengaruh profitabilitas terhadap nilai perusahaan.

Pada Tabel 12 diperoleh persamaan moderasi sebagai berikut :

Diketahui untuk nilai sig untuk baris X2Z adalah $0,033<0,05$, maka dapat disimpulkan corporate sosial responsibility berpengaruh signifikan dalam memoderasi pengaruh leverage terhadap nilai perusahaan. 
Berdasarkan tabel 12 diperoleh persamaan moderasi sebagai berikut :

Diketahui untuk nilai sig untuk baris X3Z adalah $0,882>0,05$, maka dapat disimpulkan corporate sosial responsibility tidak signifikan dalam memoderasi pengaruh ukuran perusahaan terhadap nilai perusahaan

\section{KESIMPULAN}

Profitabilitas berpengaruh secara parsial terhadap nilai perusahaan manufaktur yang terdaftar di BEI tahun 2016-2020, Leverage tidak berpengaruh secara parsial terhadap nilai perusahaan manufaktur yang terdaftar di BEI tahun 2016-2020, Ukuran perusahaan tidak berpengaruh secara parsial terhadap nilai perusahaan manufaktur yang terdaftar di BEI tahun 2016-2020, Corporate Sosial Responsibility berpengaruh secara parsial terhadap nilai perusahaan manufaktur yang terdaftar di BEI tahun 2016-2020, dan Hasil uji MRA Corporate Sosial Responsibility tidak dapat memoderasi pengaruh pofitabilitas terhadap nilai perusahaan pada perusahaan manufaktur yang terdaftar di BEI tahun 2016-2020.

\section{REFERENSI}

Bidhari, Sandhika Cipta., Salim, Ubud dan Aisjah, Siti. (2013). Effect of Corporate Social Responsibility Information Disclosure on Financial Performance and Firm Value in Banking Industry Listed at Indonesia Stock Exchange. European Journal of Business and Management, 5 (18).

Brigham \& Daves. (2010). Intermediate Financial Management. Tenth Edition. Cengage Learning: South Western.Hal. 211.

Chandrarin, Grahita. (2017). Metode Riset Akuntansi Pendekatan Kuantitatif. Jakarta: Salemba Empat

Chumaidah dan Priyadi, Maswar Patuh. (2018). Pengaruh Profitabilitas dan Size Terhadap Nilai Perusahaan dengan CSR Sebagai Variabel Moderasi. Jurnal Ilmu dan Riset Akuntansi. STIE SIA Surabaya.

Dewi, Ayu Sari Mahatma \& Wirajaya, Ary. (2013). Pengaruh Struktur Modal, Profitabilitas, dan Ukuran Perusahaan pada Nilai Perusahaan. ISSN:2302-8556. E-jurnal Akuntansi Universitas Udayana. Vol.4, hal. 358-372.

Ghozali, Imam. (2016). Aplikasi Analisis Multivariate dengan Program IBM SPSS 23. Semarang: Badan Penerbit Universitas Diponegoro

Hardian, Ananda Putra dan Asyik, Nur Fadjrih. (2016). Kinerja Keuangan dan Ukuran Perusahaan terhadap Nilai Perusahaan, CSR sebagai Variabel Moderasi. Jurnal Ilmu dan Riset Akuntansi. Vol. 5, No. 9. Hal. 1-16. STIE SIA Surabaya.

Hariyani, Iswi., Serfianto \& Cita Yustisia. (2011). Merger. Konsolidasi, Akuisisi, \& Pemisahan Perusahaan: Cara Cerdas Mengembangkan \& Memajukan Perusahaan. Jakarta: Vidimedia.

Kasmir. (2014). Analisis Laporan Keuangan. Jakarta: PT. Raja Grafindo Persada.

Mardikanto, Totok. (2014). CSR (Corporate Social Responsibility) (Tanggungjawab Sosial Korporasi). Bandung: Alfabeta.

Rodoni, Ali. \& Ali, Herlin. (2014). Manajemen Keuangan Modern. Jakarta: Mitra Wacana Media.Hal. 123 
Owner: Riset \& Jurnal Akuntansi

e-ISSN : 2548-9224 | p-ISSN : 2548-7507

Volume 6 Nomor 1, Januari 2022

DOI : https://doi.org/10.33395/owner.v6i1.614

Rosiana, Gusti Ayu Made Ervina., Gede Juliarsa \& Maria M. Ratna Sari. (2013). "Pengaruh Pengungkapan CSR terhadap Nilai Perusahaan dengan Profitabilitas sebagai Variabel Pemoderasi” E-Jurnal Akuntansi, Vol. 5 No. 3. hal 723-738. Bali: Universitas Udayana.

Taliyang, Siti Mariana., Latif, Rohaida Abdul \& Mustafa, Nurul Huda. (2011). The Determinants of Intellectual Capital Disclosure Among Malaysian Listed Companies. International Journal of Management and Marketing Research, Vol. 4, No. 3, pp. 2533,2011

Wardhany, Devi Dean Ayu., Hermuningsih, Sri \& Wijoyo, Gendro. (2019). "Pengaruh Profitabilitas, Leverage dan Ukuran Perusahaan Terhadap Nilai Perusahaan (Studi Empiris pada Perusahaan yang Tergabung dalam LQ45 pada Periode 2015-2018". Ensiklopedia of Jurnal. Vol. 2, No. 1.

Wulandari, Ni Made Intan \& Wiksuana, I Gusti Bagus. (2017). "Peranan Corporate Social Responsibility dalam Memoderasi Pengaruh Profitabilitas, Leverage dan Ukuran Perusahaan terhadap Nilai Perusahaan”. E-Jurnal Manajemen Unud, Vol. 6 No. 3 Hal. $1278-1311$ 